\title{
PEMASANGAN JARINGAN INTERNET BERBASIS WIRELESS FIDELITY (WIFI) DI KAMPUNG WANGUN CIPURUT
}

\author{
Telly Rosdiyani ${ }^{1}$, Neldiarya Setiawan ${ }^{2}$ \\ ${ }^{1,2}$ Universitas Banten Jaya, Jl Syech Nawawi Albantani Serang, Banten, Indonesia \\ Email: tellyrosdiyani004@gmail.com
}

\begin{abstract}
The Internet today makes a basic need in the fulfillment of the needs of people in the digital age, where during the COVID-19 pandemic demanded limited direct interaction to prevent the spread of viruses, the government digitized in supporting people to be able to work and learn. That certainly requires smooth internet network in each region. Similarly, in Kampung Wangun Cipurut is located in Batukuwung Village padarincang district of Serang Regency, one of the areas that is difficult to reach by other communities. Because, the terrain of the road to get to the location is still difficult to get through, so the internet network is very needed in the information of the development of the area. As for the problem how Cipurut Wangun Village requires the development of internet network, What is the purpose of Cipurut Wangun Village to build an Internet network, How to open a new business by utilizing Internet Network (Technology), How to benefit from the advancement of internet network technology that has been built one of the citizens there Author tried to create a network that could possibly be utilized for all residents of Kampung Wangun by utilizing WiFi network. Partner cooperation of a tower triangle at the central point of the server and planted several radios to channel to several points in Kampung Wangun Cipurut, The results obtained by the network become a great opportunity for the people in the village to open a home-based entrepreneurial industry facilitated by the village through BUMNDes
\end{abstract}

Keywords: Internet; Network; Village Wangun Ciputat.

\begin{abstract}
ABSTRAK
Internet saat ini menjadikan suatu kebutuhan dasar dalam pemenuhan kebutuhan masyarakat diera digital, dimana masa pandemi COVID-19 menuntut keterbatasan interaksi langsung untuk mencegah penyebaran virus. Pemerintah melakukan digitalisasi dalam mendukung masyarakat untuk dapat bekerja maupun belajar. yang sudah tentunya memerlukan kelancaran jaringan internet di setiap wilayahnya. Begitu halnya di kampung Wangun Cipurut terletak di Desa Batukuwung Kecamatan Padarincang Kabupaten Serang, salah satu daerah yang sulit terjangkau oleh masyarakat lain karena, medan jalan untuk menuju ke lokasi tersebut masih sulit untuk di lalui, jaringan internet sangat dibutuhkan dalam informasi pengembangan wilayahnya. Adapun permasalahannya bagaimana Kampung Wangun Cipurut memerlukan pembangunan jaringan internet, Apa tujuan Kampung Wangun Cipurut membangun jaringan Internet, Bagaimana membuka usaha baru dengan memanfaatkan Jaringan Internet(Teknologi),Bagaimana mendapatkan keuntungan dari kemajuan teknologi jaringan internet yang telah dibangun salah satu warga disana Dalam pengabdian masyarakat ini mencoba untuk pemasangan suatu jaringan yang bisa dimanfaatkan untuk semua warga Kampung Wangun dengan memanfaatkan jaringan WiFi. kerjasama mitra sebuah tower triangle di titik pusat server dan di tanam beberapa radio guna menyalurkan ke beberapa titik di Kampung Wangun Cipurut, Hasil yang didapatkan adanya jaringan menjadi peluang besar bagi masyarakat di kampung wangun Cipurut untuk membuka wirausaha berbasis home industri yang difasilitasi oleh desa melalui BUMNDes.
\end{abstract}

Kata kunci: Internet; Jaringan; Kampung Wangun Ciputat.

\section{PENDAHULUAN}


Kampung Wangun Cipurut terletak di Desa Batukuwung Kecamatan Padarincang Kabupaten Serang, terdapat 115 kepala keluarga (KK) dengan 500 jiwa bermukim di dua kampung itu. Sebarannya, 35 KK di Kampung Wangun Pakis dan 80 KK di Kampung Wangun Tarikolot. Kebanyakan mereka menggantungkan hidup dari hasil bumi sebagai petani baik kebun dan sawah. Sudah pasti berpenghasilan minim, juga tak menentu. Kadang seminggu sekali, hasil panen meliputi gabah, singkong, melinjo, dan pisang dijual ke pasar terdekat yakni Pasar Padarincang. Jaraknya sekira empat kilometer $(\mathrm{km})$ dari kampung. Setelah dikurangi ongkos ojek, paling-paling dapatnya Rp100 ribu. Malah, bisa kurang dari Rp100 ribu.

Sarana transportasi di sana terbatas. Warga hanya bisa memanfaatkan jasa ojek dengan merogoh kocek lebih dalam. Sekali jalan -pulang dan pergi- warga harus mengeluarkan uang Rp30 ribu. Nilai segitu untuk seukuran warga di sana tergolong besar. Bisa untuk makan sekeluarga. Jasa ojek juga hanya beroperasi ketika kondisi jalan kering. Jika turun hujan, mereka tak mau ambil risiko. Kalau sudah begini, warga terpaksa berjalan kaki. Jarak yang ditempuh lumayan jauh. Bisa menghabiskan waktu satu jam. Meski kampung sudah teraliri listrik, warga lebih banyak menumpang secara paralel ke rumah warga lain yang berlistrik. Bahkan akan internet masih belum tersosialisasikan pada daerah tersebut sedangkan sarana komuniksi ini diperlukan dalam pengembangan wilayah, berikut posisi lokasi sebagai berikut

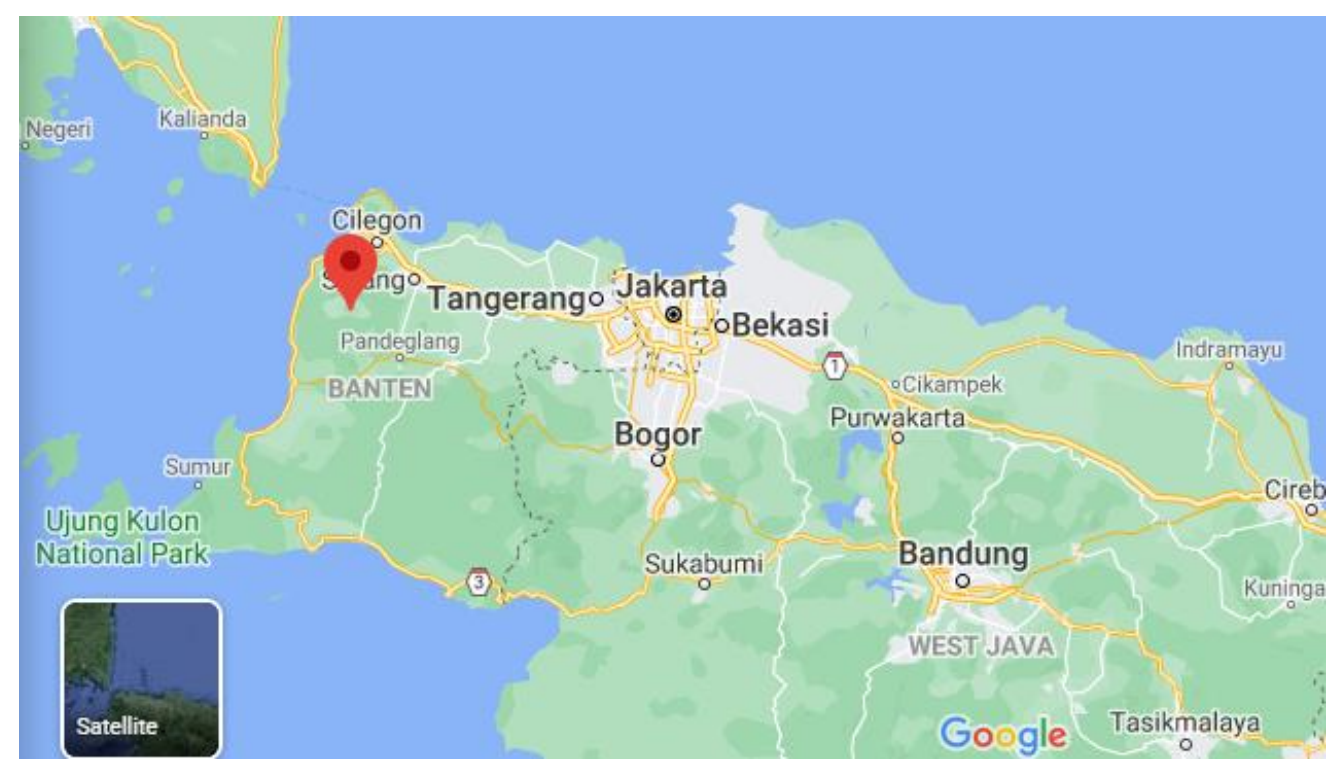

Gambar 1. Peta Lokasi Kampung Wangun Cipurut 
Berdasarkan data Tim Nasional Percepatan Penanggulangan Kemiskinan (TNP2K) 2016, selain Desa Batu Kuwung, ada 26 desa/kelurahan termiskin di Provinsi Banten yang tersebar di delapan kabupaten/kota.

Dari 1.542 desa/kelurahan di Provinsi Banten, TNP2K menetapkan 27 desa/kelurahan daerah tertinggal dan paling miskin dibanding desa/kelurahan lain dengan jumlah 28.802 kepala keluarga (KK) atau sekira 119.791 jiwa. Khusus di Kabupaten Serang, ada empat desa yang masuk kategori tertinggal dan termiskin yaitu Desa Batukuwung, Kecamatan Padarincang; Desa Citasuk, Kecamatan Padarincang; Desa Umbultanjung, Kecamatan Cinangka; dan Desa Sukasari, Kecamatan Tunjung Teja.

Mengacu pada data TNP2K yang kemudian dirilis Bappeda Banten, di Desa Batukuwung terdapat 7.602 jiwa penduduk dengan jumlah rumah tangga (RT) sebanyak 1.740. Lebih dari 40 persen dari jumlah RT masuk dalam rumah tangga miskin (RTM) dan $116 \mathrm{KK}$ tercatat kepala rumah tangganya adalah perempuan. Sementara anak usia sekolah yang tidak bersekolah di Desa Batukuwung sebanyak 274 anak, dan 480 KK tidak memiliki MCK. Kemudian 22 warga Desa Batukuwung dalam kondisi cacat dan 5 warga mempunyai penyakit kronis. Sementara warga yang menganggur sebanyak 2.076 orang dan warga yang bekerja di sektor pertanian 442 KK. Data TNP2K juga menyebutkan, 339 KK kesulitan mendapatkan air bersih. Untuk fasilitas pendidikan, baru sampai tingkat SD dan SMP satu atap (satap) fasilitas sarana eletronik dapat memudahkan namun lokasi yang perlunya pembenahan.

Internet merupakan salah satu bagian dari teknologi informasi dan komunikasi, sebuah jaringan yang menghubungkan komputer dengan menggunakan standar global transmission control (TCP) sebagai protokol pertukaran, internet ini mendapatkan kemudahan pertukaran informasi serta berkomunikasi transformasi internet dari jaringan kabel, jaringan tanpa kabel (wireless) dan satelit (Priantama, 2017). Dengan Teknologi, informasi dan komunikasi bisa dilakukan secara langsung meski kita berada di tempat yang sangat jauh dengan orang yang kita ajak untuk melakukan saling tukar informasi dan berkomunikasi suatu kebutuhan dasar dalam pemenuhan kebutuhan masyarakat diera digital maka dapat disimpulkan karakteristik dari internet ini memiliki jaringan yang sangat luas (Internasional bahkan Sedunia), memiliki jaringan yang kuat, perkembangan yang sangat pesat dan bias diakses kapan saja dan dimana saja, dengan karakteristik yang dimiliki menjadi solusi sebagai sarana komunikasi terutama masa pandemi COVID-19 saat ini yang menuntut atau membatasi interaksi langsung untuk mencegah penyebaran virus.

Hal itu sudah tentunya memerlukan kelancaran jaringan internet di setiap wilayahnya begitu halnya yang dihadapi di kampung Wangun Cipurut. Kampung ini terletak di Desa 
Batukuwung Kecamatan Padarincang Kabupaten Serang, salah satu daerah yang sulit terjangkau oleh masyarakat lain. Karena, medan jalan untuk menuju ke lokasi tersebut masih sulit untuk di lalui. Jalan masih berbatu. cukup jauh dari jalan utama sekitar berjarak 5 kilo dari Jalan Raya Ralka, Sehingga jalur atau sinyal internet tidak dapat menjangkaunya, Sehinga pihak ISP atau telkom berpikir ulang untuk bisa membuat jalur internet masuk ke desa tersebut, dengan pertimbangannya memerlukan dana yang sangat besar, secara teknis pelaksanaan juga yang sangat sulit. Menitik perlunya suatu informasi dalam pengabdian pada masyarakat ini menawarkan pendampingan dan sosialisasi perlunya suatu informasi dengan cara pemasangan jaringan internet yang mengandalkan signal atau WiFi untuk dapat menjangkau daerah pedalaman agar menggunakan internet dengan nyaman dan murah . Kegiatan ini sebagai bahan pengabdian kepada masyarakat yang mana suatu tuntutan tri darma perguruan tinggi dalam lingkup akademisi. Adapun permasalahannya yang dihadapai antara lain bagaimana Kampung Wangun Cipurut memerlukan pembangunan jaringan internet, Apa tujuan Kampung Wangun Cipurut membangun jaringan Internet, bagaimana membuka usaha baru dengan memanfaatkan Jaringan Internet (Teknologi) serta Bagaimana mendapatkan keuntungan dari kemajuan teknologi jaringan internet yang telah dibangun. Berdasarkan permasalahan diatas kami menawarkan solusi dalam mempermudah transpormasi informasi komunikasi dan pengembangan dalam potensi daerah.

\section{METODE PELAKSANAAN}

Metode yang gunakan dalam perencanaan ini meliputi beberapa tahap, berikut tahap pelaksanaan yang kami buat antara lain (Burges, 2011):

\section{Perencanaan}

a. Survei

Pada metode ini mencari data seberapa jauh mencari titik untuk mendapatkan sinyal, dan seberapa jauh kita harus menyalurkan radio wireless dari titik awal server ke Kampung Wangun Cipurut. Selain itu kami juga meneliti seberapa banyak penghalang sinyal WiFi yang di sebabkan banyaknya pepohonan karena akses ke Kampung Wangun Cipurut merupakan hutan pegunungan. Survei ini kami lakukan dengan beberapa tahap observasi untuk mendapatkan sesuatu titik sinyal yang pas dalam penyebaran sinyannya

\section{b. Perancangan Alat}

Pada metode ini rancangan sebuah tower triangle di titik pusat server dan di tanam beberapa radio guna menyalurkan ke beberapa titik di Kampung Wangun Cipurut, pada server tersebut di berikan sebuah alat tambahan untuk membagi bandwitch pada setiap User 
yang bernama Microtic. Di setiap titik di Kampung Wangun Cipurut kami bermaksud menyediakan sebuah alat pemancar sinyal (acess point) berjarak sekitar 100-200 meter.

2. Persiapan Kegiatan

Persiapan kegiatan yang dilakukan meliputi :

a. Bermusyawarah dengan Mitra, hal ini dimaksudkan untuk dapat mendiskusikan bantuan mitra dalam sifatnya pengabdian pada masyarakat

b. Survei harga peralatan penunjang dan bahan habis pakai, kergiatan ini merangkum bahan dan peralatan yang dibutuhkan dalam perakitan alat dan bahan untuk dapat disosialisasikan kepada masyarakat.

c. Survei lokasi Mitra

3. Pengadaan Alat dan Perlengkapan Kebutuhan

Tahap ini merupakan tahap lanjutan setelah tahap persiapan kegiatan terlaksana, yaitu berupa penyiapan alat serta perlengkapan kebutuhan untuk menunjang kesiapan proses pemasangan. Alat yang diperlukan diantaranya sebagai berikut:

a. Access point

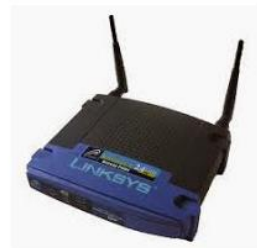

\section{Gambar 2. Contoh Access Point}

b. Wireless access point router

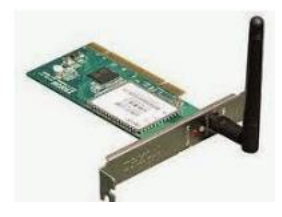

Gambar 3. Contoh Wireless Access Point Router

c. Wi-fi USB Adapter

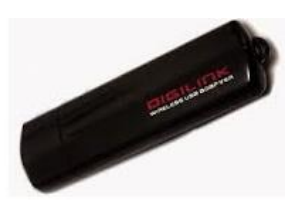

Gambar 4. Contoh Wifi USB Adapter 


\section{Proses Perancangan Alat}

Proses perancangan alat ini membutuhkan beberapa tahapan (Hart, 2017), yaitu:

a. Topologi Jaringan, adalah, hal yang menjelaskan hubungan geometris antara unsur-unsur dasar penyusun jaringan, yaitu node, link, dan station. Pemilihan topologi jaringan didasarkan pada skala jaringan, biaya, tujuan, dan pengguna. Topologi-topologi ini sering kita temui di kehidupan sehari-hari, tetapi kita tak menyadarinya. Contoh Topologi yang digunakan adalah topologi bus. Semua Topologi memiliki kelebihan dan kekurangan tersendiri.

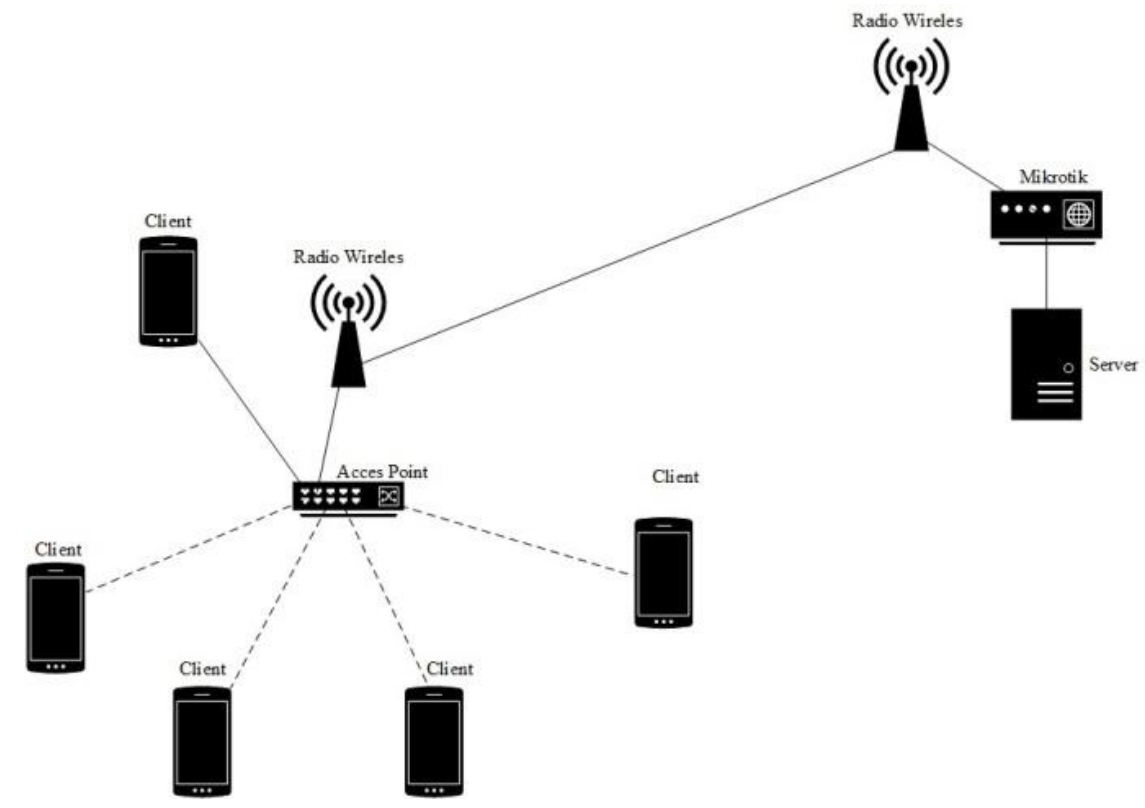

\section{Gambar 5. Teknologi yang Digunakan}

b. Pemilihan Alat sesuai Kebutuhan

c. Perhitungan kekuatan sinyal

d. Pembagian Speed Internet (Bandwidth)

\section{Uji Coba dan Penelitian}

Setelah jaringan internet kita buat pada tahap ini kita melakukan uji coba untuk mengetahui seberapa bagus kekuatan sinyal yang ditangkap dari server dengan kendala pepohonan, tembok, dan penghalang lainnya. 


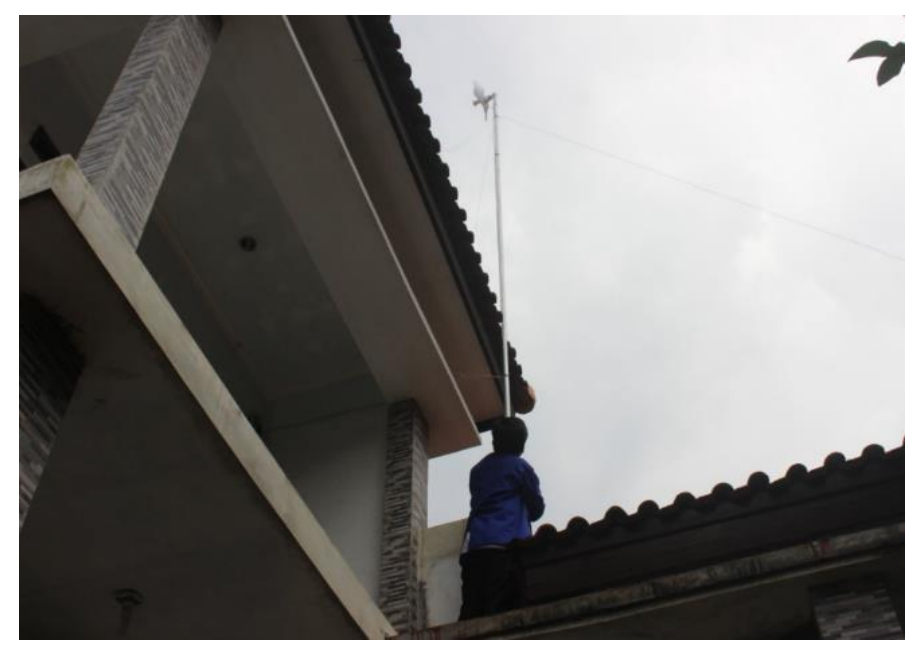

Gambar 6. Pencarian Sinyal

6. Evaluasi

Untuk meningkatkan kualitas sinyal yang baik, maka perlu di evaluasi anatara lain:

a. Kekuatan Sinyal apakah stabil atau tidak

b. Kecepatan yang didapat dengan beberapa kendala seperti terhalang pepohonan atau yang lainnya

c. Alat yang dibutuhkan apakah mampu untuk menjangkau dengan skala besar

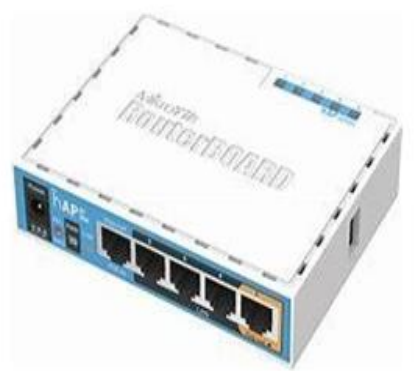

\section{Gambar 7. Alat Mikrotik yang Digunakan}

d. Seberapa efektif kekuatan radio wireless dalam menagkap sinyal dari server

\section{Perbaikan}

Setelah melewati tahapan evaluasi, tahapan berikutnya adalah melakukan perbaikan dari segi permasalahan alat dan kondisi yang ditemukan untuk mendapatkan hasil yang optimal. 
8. Flowchart Perancangan dan Implementasi

Perancangan dan implementasi jaringan hotspot WiFi di Kampung Wangun Cipurut melalui beberapa proses agar sistem yang dibuat mendapat hasil yang baik dan sesuai dengan tujuan pembuatan sistem. Proses perancangan dan implementasi jaringan hotspot WiFi di Kampung Wangun Cipurut disimulasikan dalam sebuah flowchart berikut.

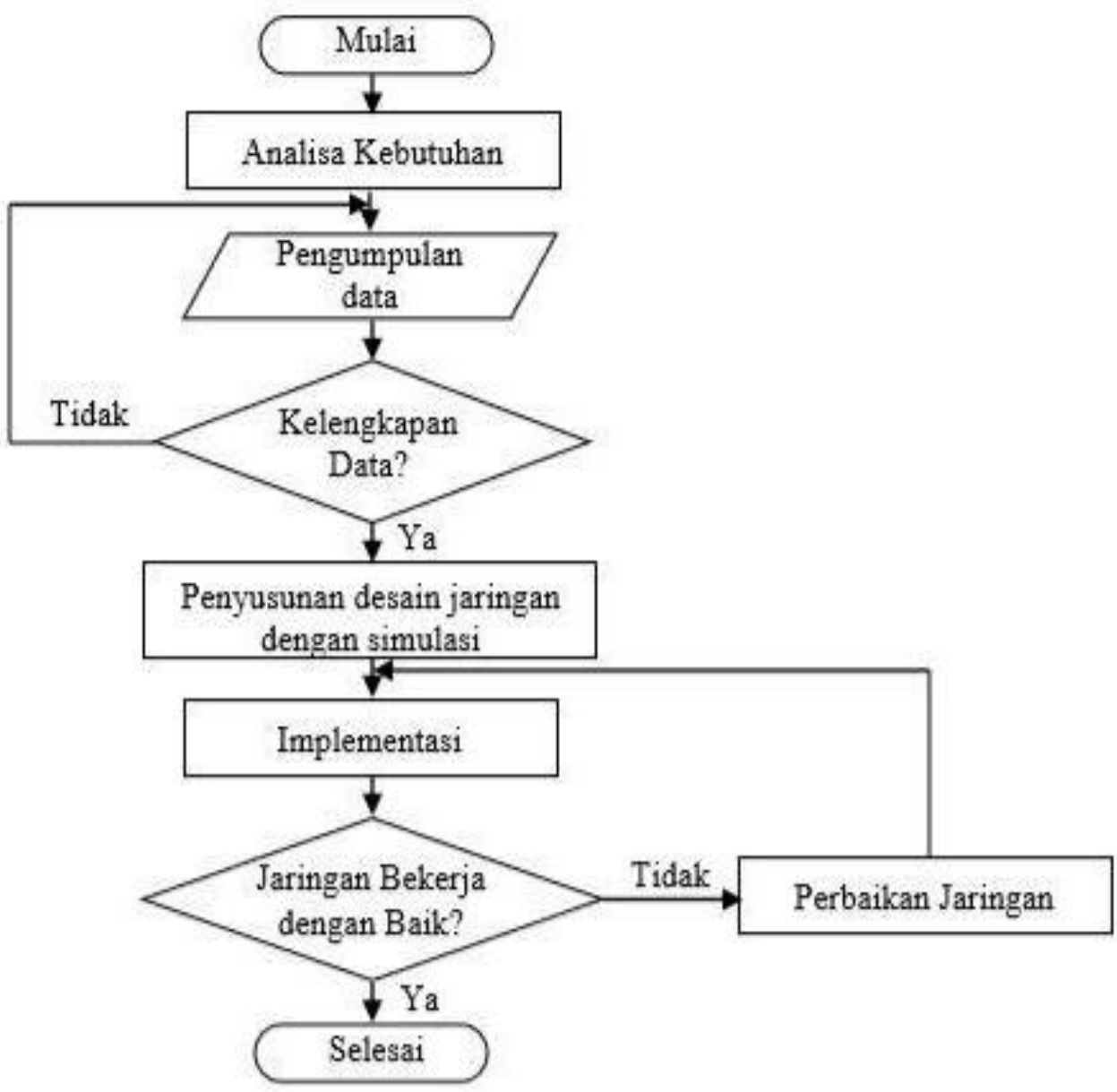

\section{Gambar 8. Flowchart Perancangan dan Implementasi}

\section{HASIL DAN PEMBAHASAN}

Dengan kondisi wilayah Kampung Wangun Cipurut yang ada di dataran tinggi dan akses menuju lokasi ini harus melewati hutan sepanjang $2 \mathrm{~km}$, tentu sangat sulit menjangkau sinyal yang dapat terima warga. Jaringan internet susah didapatkan pada wilayah kampung ini untuk membuat jaringan yang bisa dimanfaatkan untuk semua warga Kampung Wangun dengan melakukan memanfaatkan jaringan WiFi. Kami dengan mitra layanan jasa internet melakukan kerjasama untuk penempatan di Kampung Wangun Cipurut, dengan adanya akses internet ini 
diharapkan masyarakat dapat meningkatkan pengetahuan mereka dengan memperoleh berbagai informasi positif yang diterima dari luar. Misalnya dalam hal penjualan emping melinjo secara online, dan perkembangan teknologi informasi yang cepat, serta dapat dimanfaatkan untuk sekolah yang ada disana yang mengharuskan pembelajaran di rumah selama masa pandemi covid-19.

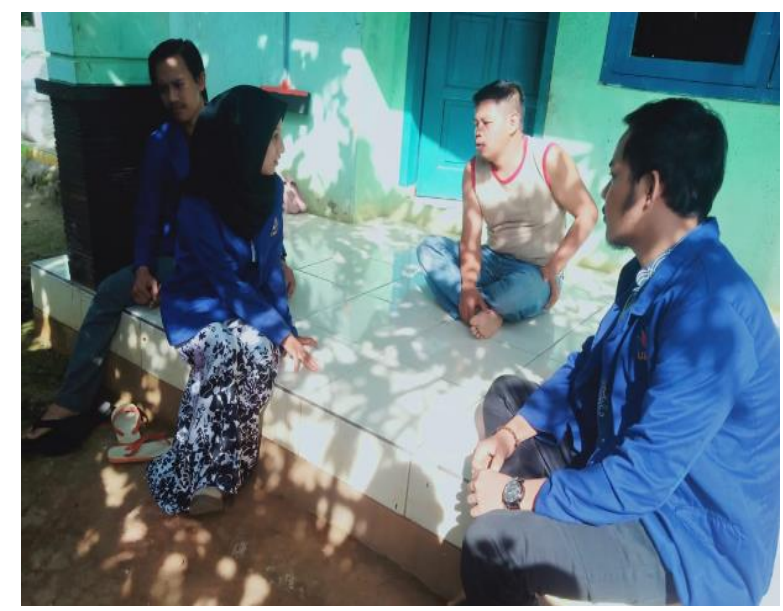

\section{Gambar 9. Wawancara dengan Ketua RW Setempat}

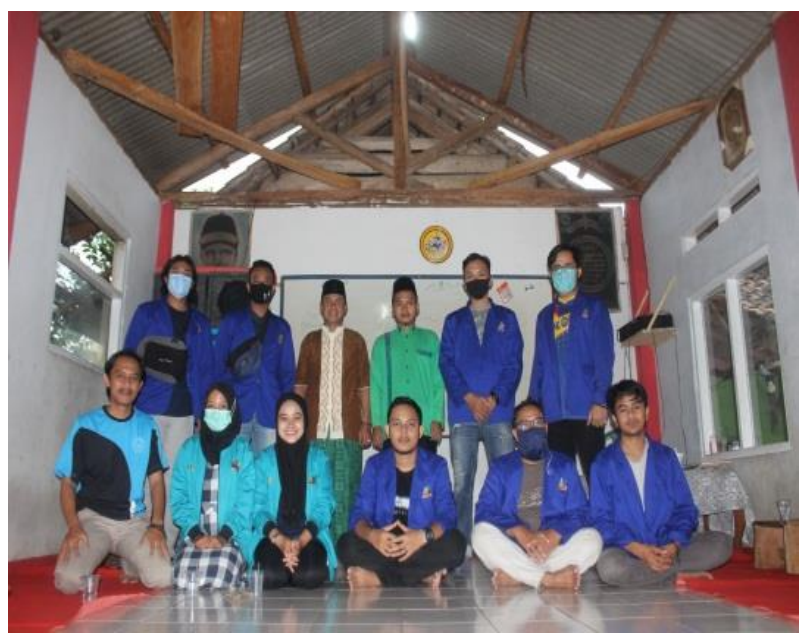

\section{Gambar 10. Kegiatan Sosialisasi dengan Warga}

Pengadaan Wifi dengan kerjasama mitra serta perancangan sebuah tower triangle di titik pusat server dan di tanam beberapa radio guna menyalurkan ke beberapa titik di Kampung Wangun Cipurut, pada server tersebut di berikan sebuah alat tambahan untuk membagi bandwitch pada setiap user yang bernama mikrotik. Setiap titik bermaksud menyediakan sebuah alat pemancar sinyal (acess point) yang berjarak sekitar 100-200 meter. 


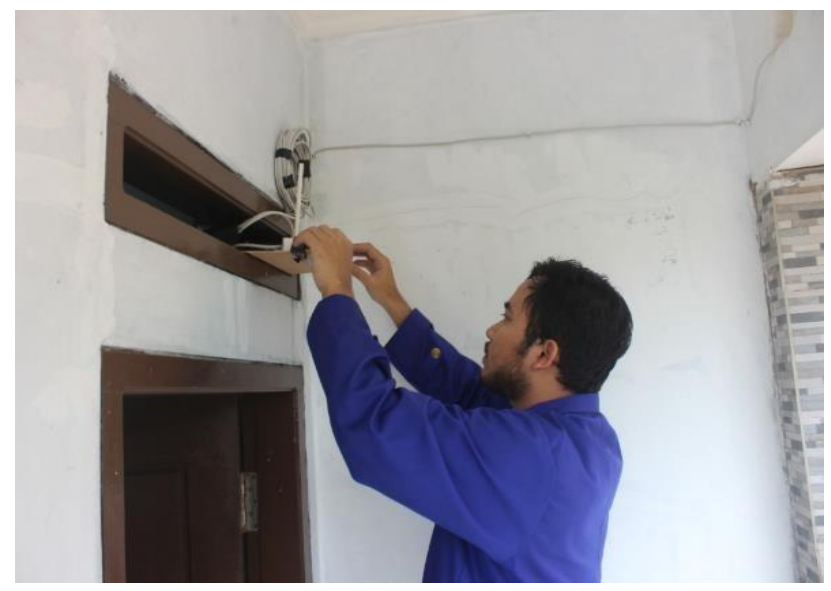

Gambar 11. Pemasangan Jaringan Internet

\section{KESIMPULAN}

Secara umum potensi yang dimiliki oleh Kampung Wangun Cipurut, Desa Batukuwung, Kecamatan Padarincang, Kabupaten Serang ini cukup besar dari segi keindahan alam maupun banyaknya para pengrajin melinjo sehingga pengembangan kapasitas Jaringan Internet sangat diperlukan. Dalam hal ini Jaringan internet sebuah perancangan tower triangle di titik pusat server dan di tanam beberapa radio guna menyalurkan ke beberapa titik di Kampung Wangun Cipurut, pada server tersebut yang di berikan dengan sebuah alat tambahan untuk membagi bandwitch pada setiap user yang bernama mikrotik mampu membantu penguatan sinyal internet wilayahnya sehingga dapat mengembangkan wirausaha, terutama pengolahan bahan baku dan pemasaran produksi melinjo maupun informasi lainnya misalnya menjadi beraneka ragam olahan Hal ini menjadikan peluang besar bagi masyarakat di kampung wangun cipurut untuk membuka wirausaha berbasis home industri yang difasilitasi oleh desa melalui BUMNDes, akan sangat memungkinkan desa ini mempunyai ikon tersendiri.

\section{UCAPAN TERIMAKASIH}

Ucapan terimakasih disampaikan kepada ;

1. Ketua LPPM Universitas banten Jaya yang telah memberikan kesempatan dan dukungan untuk melaksanakan kegiatan Kuliah Kerja Nyata dengan tema "Peran Aktif Mahasiswa di Era Pandemi Covid-19 Guna Meningkatkan Produktivitas Masyarakat di Kampung Wangun Cipurut." 
2. Kepada Ketua Pelaksana KKM atas kesempatan dalam hal pengabdian pada masyarakat

3. Bapak Aeng Haerudin, selaku Kepala Desa Batukuwung yang sudah mengizinkan melaksanakan pengabdian di Desa Batukuwung, Kecamatan Padarincang, Kabupaten Serang.

4. Bapak Abdul Rohman, selaku Ketua RT Dusun Wangun Cipurut yang senantiasa memberikan arahan, nasihat, bimbingan, serta dukungannya dalam pelaksanaan pengabdian pada masyarakat

5. Semua pihak yang tidak dapat kami sebutkan satu persatu yang telah membantu terlaksananya tugas pengabdian ini.

\section{DAFTAR PUSTAKA}

Burgess, D (2011). Learn RouterOS (2 ed.). p. 26. Link Technologies,Inc ISBN 978-1-10506959-8.

Hart, T. (2017). Networking with MikroTik: MTCNA Study Guide. Independently published. Priantama, R. (2017). Efektivitas Wifi Dalam Menunjang Proses Pendidikan Bagi Lembaga Perguruan Tinggi (Studi Kasus Terhadap Mahasiswa Pengguna Di Lingkungan Universitas kuningan), Jurnal Cloud Information, Vol 1 No1 ISSN 2527-5224. 